\title{
Analysis of National Peculiarities and Challenges of Development of the Organizational Culture of Mongolia
}

\author{
Vyacheslav K. Sevek ${ }^{\mathrm{a}}$, Amarsanaa Bor ${ }^{\mathrm{b}}$ \\ and Ruslana M. Sevek ${ }^{\text {a* }}$ \\ a Tuvan State University \\ 36 Lenin Str., Kyzyl, Republic Tuva, 667000, Russia \\ ${ }^{b}$ Institute of Finance and Economics \\ 5 Peace Avenue, Ulaanbaatar, 13381, Mongolia
}

Received 15.09.2016, received in revised form 27.06.2017, accepted 06.07.2017

The article presents an analysis of the national features of the organizational culture of Mongolia, taking into account the study of its historical stage of development. The purpose of the paper is to define a contemporary national model for Mongolian corporations' management. The determination of the factors of the national organizational culture on the basis of the analysis of the Mongolian state's development stages, beginning with the culture of nomads to the urbanized modern culture were the research methods. It is revealed that all these cultures interact and are interconnected with each other and, thus, form a kind of mixture of cultures - a specific culture of a mixed type, characteristic of the contemporary Mongolian corporate governance. The impact of this factor on companies and corporations operating in the world markets and wishing to ensure competitiveness is being updated due to the constantly changing demands of the outer world.

Keywords: analysis, national culture, organizational culture, company, corporation, management, Mongolia.

DOI: 10.17516/1997-1370-0110.

Research area: culturology.

\section{Introduction}

Since the early 1980s of the last century the attention to the study of organizational culture has been actively raising. It is explained by the fact that under conditions of market relations, production and commercial activities of corporation require an orientation towards a new model of entrepreneurship. Considering entrepreneurship as a process, it can be seen that it is closely related to the cultural environment that is formed from the external culture (society) and the internal culture of business partners (Savchenko, 2008, 2005; Kovalenko, Semenchenko, 2015, 2014).

In order to determine the specific features of the organizational culture of Mongolian corporations, first of all it is necessary to understand the national culture peculiarity. At that, it should be noted that the organizational

(C) Siberian Federal University. All rights reserved

* Corresponding author E-mail address: vsevek@mail.ru; amarsanaa.b@ife.edu.mn; sevrusmon@mail.ru 
culture is greatly influenced by the peculiarities of national culture, which is a "symbiosis" of three cultures: a) the culture of nomads, which has been formed and developed throughout the history of Mongolia; b) the "urbanized" culture of modern Mongolia; c) the culture of corporate business, formed under the influence of the globalization factor.

Regardless of the corporation management model and according to the classification criteria (by name, orientation, etc.) ${ }^{1}$, it can be stated that the national and organizational cultures are the influencing factors. The use of these models, without regard to the national peculiarities, both in the corporations of Mongolia, and in the corporations of other countries, is critical.

\section{Statement of the problem}

Relying on the studied models of corporate governance and the factors of organizational culture (Bor, et al., 2016) which affect management, it is reasonable to analyze and determine the contemporary national model of Mongolian corporations' management. For this, it is necessary to study the accumulated world experience, the specific features of the national mentality of the population of Mongolia, to hold the historical chronology of Mongolia from the moment of the state education emergence to the present time. We believe that this approach to the study will allow us to comprehensively and consistently study the main factors of organizational culture that form and develop the national model of modern Mongolian corporations' management.

\section{Discussion}

Transformation processes that have taken place in the territory of Mongolia (Sevek, 2015, 2016a):

1. The Hunnic state (Хүнну гүрэн) 209 B.C. -93 (156) A.D.
2. The Turkic Khaganate (Түрэгулс) 552747 A.D.

3. The Uyghur Khaganate (Уйгур улс) 744-840 A.D.

4. The Khitan state (Хидан (Хятан) гүрэн) 907-1125 A.D.

5. The Great Mongol Empire $-12^{\text {th }}-17^{\text {th }}$ centuries.

6. The period of the reign of Manchu, the Qing Dynasty - the $17^{\text {th }}$ century - the early $20^{\text {th }}$ century.

7. The Mongolian People's Republic (the period of planned economy) - early $20^{\text {th }}$ century late $20^{\text {th }}$ century.

8. Mongolia (the period of market economy) - late $20^{\text {th }}$ century - till the present time.

In the authors' opinion, it is important to reflect the historical chronology of Mongolia from the moment of the public education emergence.

The period of the Great Mongol Empire

Around 924 the tribes of the Turks left the territory of the present-day Mongolia and after that the Mongols started governing in their own territory. Except for a short period of Khitan rule, the Mongols lived in tribes without forming a unified state. In the $13^{\text {th }}$ century there were numerous tribes (Naimans, Tatars, Khamag Mongols, Khereid, Onyuds, Mergeds, etc.) in the territory of Mongolia. After the Khamag Mongolian Khabul Khan, the Mongolian tribes were without a leader till the time when at the Great Khuralday in 1206, his descendant Temujin united all the tribes, was proclaimed the khan of all Mongols and was given the title Genghis Khan. Separate and warring Mongolian nomadic tribes united into a single state (Gerelmaa, Odmandakh, 2007).

Having become the all-Mongol leader, Temujin in his policy even more vividly represented the interests of noyans ${ }^{2}$. To consolidate their rule and increase their incomes 
noyans needed to rob rich countries. The new wars of conquest were to ensure the strengthening of the class positions and the expansion of the sphere of feudal exploitation.

The management model and system created by Genghis Khan was adapted to the implementation of these goals. Having, thus, mixed the tribes and clans, and appointing specially selected people from the proxies and nökürs as their leaders, he divided the entire population into foremen, centurions, thousandmen and tumens (ten thousand). Healthy and adult men were all considered warriors, who at peacetime managed their farms, and at wartime fought. This organization provided Genghis Khan with the opportunity to increase his armed forces to about 95 thousand soldiers. Separate centurions, thousandmen and tumens were given into possession to a noyan along with the territory for nomadism. The Great Khan gave the land to the noyans' possession under the condition that they would perform certain duties for this properly. Military service was the most important of these duties. On the first demand each noyan was required to put the required number of soldiers in the field. Giving out his livestock to grazing or drawing them directly to work, a noyan had the right to exploit the labor of arats (Mongolian cattle breeders) in his household.

Under Genghis Khan it was forbidden to arbitrarily move from one foreman (centurion, thousandman or tumen) to others, and the enslavement of the arats was legalized. For the departure from the possessions the arat threatened death penalty. The ban meant the formal arats' belonging to the noyans' land (Lhaasid, Badralmaa, 1996). Genghis Khan made a written law the cult and was a supporter of tough law and order. He created a network of communication lines in his empire, courier communication in a large scale for military and administrative purposes, organized reconnaissance, including economic. He divided the country into two "wings". He appointed two of his most faithful and experienced fellow-thinkers as the leaders of the right wing. He made the title and the position of senior and highest ranking military commanders, who helped him to gain control of the khan's throne by their faithful service, hereditary in the family. The Mongols, without any doubts, were the dominant people in the $13^{\text {th }}$ century, and Mongolia became known throughout the world (Narantsetseg, 2007).

The period of the reign of Manchu, the Qing Dynasty

The period of the Manchu dynasty Qing. In the early $17^{\text {th }}$ century the Manchu, who lived in the northeast of the present-day China, unexpectedly quickly started to gain strength. They attacked the separated tribes of the Mongols and forced them to pay tribute. In 1636 the Manchu annexed Inner Mongolia. After the capture of Beijing in 1644, they founded the Qing dynasty and united all China for two years. Then they turned their attention to the north towards Mongolia. As a result of the conflicts between the Khalkha (a group of the eastern peoples of Mongolia) and the Oirats (a group of Western Mongolian peoples), as well as the skillful heating confrontation on the part of Tibet, the Manchu managed to annex Mongolia in 1696. After the signing the Treaty of the Qing Empire with Russia in Kyakhta in 1725, the Russian-Chinese border was completely defined. Taking advantage of the weakness of the split of the Oirats, the Manchu army of 50,000 soldiers defeated them and annexed to the empire in 1755. Thus, the Manchu annexed Mongolia to China after 130 years of effort. In 1755-1757 the Oirats started an uprising and, at the same time, there was resistance from the Khalkha. Military units were deployed in Uliastai as a precautionary measure to protect against the Mongols. In administrative terms Mongolia was 
divided into 4 Khalkha and 2 Durbet (дөрвөд) aimaks, totally 125 Khoshuns (administrative units during the reign of the Manchu). Since Bogdo-gegen Jebtsundamba supported Amarsan, the leader of the uprising, it was decided in Beijing to invite follow-on Bogdo-gegens only from Tibet. The residence of Bogdo-gegen was located in Da Khuree (Urga). Later, the office of amban in Hobdo and customs in Kyakhta were created. In Beijing, the Ministry for Mongolia Affairs "Jurgan" was founded, through which the relations between the Mongols and the ManchuChinese Empire were established. The Manchu themselves were half nomadic. In this regard, to prevent Sinification, they banned all Mongolian relations with the Chinese. Chinese traders were allowed to come to Mongolia only for a short time and on a certain route and were forbidden to live there permanently and conduct any other activity other than trade.

Thus, at that time Mongolia was a vassal province of the Manchu Qing Empire with special rights. But later the small population of Manchuria was assimilated by the Chinese. The early $20^{\text {th }}$ century found Mongolia on the verge of total impoverishment and ruin. The Manchu yoke had a disastrous effect not only on the material conditions of the life of Mongolian people, but also on its physical condition. At the same time, there were a lot of foreign usury merchants in the country, in whose hands enormous wealth was accumulated. The discontent was growing in the country, spilling out into spontaneous attacks by the Arats against the Manchu authorities. As a result, by 1911, Mongolia was in the condition for a nationwide struggle to overthrow the more than two centuries of the Manchu yoke. In July 1911, in Urga (present Ulaanbaatar) secretly from the Manchu authorities a meeting, in which the largest secular and spiritual leaders led by Bogdo-gegen (the Holiest Bogdo) took part, was held. Taking into account the new course of the
Manchu policy and the mood of the Mongolian people, the participants of the meeting recognized that it is impossible for Mongolia to remain longer under the rule of the Qing dynasty. At this time the national liberation movement was rapidly developing throughout the country, starting from Urga to the province of Khovd.

On December 1, 1911, an appeal to the Mongolian people, which said: "Our Mongolia was an independent state from the very beginning of its existence, and therefore, according to the ancient law, Mongolia declares itself independent of other authorities in its affairs. With that knowledge in mind it is declared that we, Mongols, from now on, do not submit to the Manchu and Chinese officials, whose authority is completely destroyed, and they must, therefore, return to their homeland", was published. On December 4, 1911, the Manchu ambassador Sando and his other officials left Urga for China.

On December 29, 1911 in Urga in the monastery of Dzun-khuree, the ceremony of accession of the head of the Lamaist church of Bogdo-gegen, who received the title of "accessed by many", to the Khan's throne took place. Thus, as a result of the liberation movement of Mongolian aratia, the country gained its freedom in more than two hundred years and was restored as an unlimited feudal-theocratic monarchy, which was an objectively progressive phenomenon of the country.

A government with five ministries was formed and the city of Khuree was declared as the capital. After the liberation of Hobdo, the Oirats, as well as the Barga, and most of the Khoshuns of Inner Mongolia joined them. As a result of long disputes in 1915, a historical tripartite RussianMongolian-Chinese agreement was concluded in Kyakhta. China wanted to subjugate Mongolia completely, and the Mongols fiercely resisted. Russia was interested in creating the autonomy only in Outer Mongolia and was trying to 
achieve this. After years of disputes, Mongolia agreed that Inner Mongolia would be completely subordinated to China, and Outer Mongolia would be an autonomy with special rights under Chinese sovereignty.

In 1917, the October Revolution took place in Russia. Then there was a long civil war. Having lost its autonomy, Mongolia asked for help from different states. Bodoo and Danzan, representatives of the People's Party, visited Russia. But Soviet Russia considered Mongolia as a part of China and refused to expel Chinese troops from the country. The Mongolian People's Army under the command of Sukhbaatar and the part of the Soviet Red Army that came to the aid of the Mongolian people from May to August 1921 defeated the White Army troops of Lieutenant-General Baron von Ungern Sternberg. And on July 6, 1921 Urga (now Ulaanbaatar) was liberated. On July 10, the Provisional People's Government was reorganized into the Permanent People's Government and Sukhe-Bator became a member of it, taking up the post of the Minister of War. Soviet Russia was not agree with the independence of Mongolia, but in 1921 recognized the government under the leadership of Bodoo. The new government held the coronation of the Bogdo-Gegen and founded a limited monarchy. Serfdom was also abolished and a course for creation of a modern and civilized state was taken.

Moscow and Beijing had postponed the solution to the problem of Mongolia's independence for a long time. However, in May 1924, the Soviet Union and the Chinese Government signed an agreement that Mongolia was a part of China. The Soviet Union also reached an agreement with the leaders of the Chinese Kuomintang to carry out the Red Revolution in all China, including Mongolia. Thus, Mongolia became the object of inexplicable and poorly harmonized treaties between the Soviet Union, the Government of China and the leaders of the Kuomintang.

The Period of the Mongolian People's Republic (planned economy)

In 1924 Mongolia declared the formation of the People's Republic and adopted the Constitution. After the death of Bogdo-Khan Jebtsundamba there was a need to choose the form of government for Mongolia. In the period of the new constitution development, the first State Khural was convened. Khural did not accept the first draft of this constitution, accusing the constitutional commission of copying the constitutions of the capitalist countries. A new draft constitution, which was subsequently adopted, was developed in Moscow. The capital of Khuree was renamed Ulaanbaatar. The main significance of the Constitution was that it proclaimed the formation of the People's Republic.

Since 1936 Kh. Choibalsan, who previously held the post of Minister of Defense became the head of Mongolia. According to contemporary Mongolian historians (Niamsuren, 2014), Choibalsan was almost the most despotic leader of Mongolia in the last century. At the same time, due to his actions in Mongolia, mass literacy was achieved (Kh. Choibalsan abolished a rather complicated ancient Mongolian alphabet and introduced the Cyrillic alphabet), from the agrarian country Mongolia turned into an agrarian-industrial one. Despite the fact that Kh. Choibalsan's regime is criticized by the contemporaries, Kh. Choibalsan's efforts to preserve Mongolia's independence are emphasized.

\section{Mongolia during the Second World War.} In the mid-1930s, the Japanese created the puppet state of Manchukuo and raised a controversial issue about the border with Mongolia. In May 1939, it turned into an armed conflict. The Soviet Union sent its troops to help Mongolia. Having 
pulled up additional forces, the Kwantung Army launched a war that lasted until September. In September 1939, in Moscow, according to the agreement between four countries (Mongolia, Manchukuo, the USSR and Japan) the war that cut off 70,000 lives was officially over.

During the Great Patriotic War (1941-1945), Mongolia helped the Soviet Union in its struggle against the fascist Germany as far as possible: about half a million horses were given; a tank column and an air squadron of fighter planes were created on the funds collected by the Mongolian people. Dozens of echelons with warm clothes, food and various gifts were also sent to the front. At the final stage of the Second World War, the Mongolian People's Army, as part of the horsemechanized group of Soviet-Mongolian troops, took part in the defeat of militaristic Japan.

At the difficult time of the war Mongolian State University was founded on October 5, 1942 (Sevek, 2016b). A lot of outstanding professors came from the USSR and took part in its opening. Mongolia started training its professional personnel (Sevek, Batzhargal et al., 2016; Sevek, Dorligzhavyn et al., 2016), which was a powerful impetus in the cultural and social development of the country. Mongolia also sent a lot of students to study in the USSR. About 54,000 Mongols got education in the Soviet Union, 16,000 of them received higher education. They began to develop their country and turned it into a state of the $20^{\text {th }}$ century.

In 1945, a plebiscite on the issue of the independence of Mongolia was held. According to the Yalta Agreement, the status quo of Mongolia was recognized. The Chinese government decided that if the Mongols confirmed their independence, then China would agree to recognize it. In October 1945, a nationwide plebiscite was organized. On its basis China on January 6, 1946 and the USSR on November 27, 1946 recognized the independence of Mongolia.
The struggle for independence, which lasted for almost 40 years, was successfully completed, and Mongolia became a truly independent state.

The period of socialism. In 1947, a railway line connecting Naushki and Ulaanbaatar was built. Only in 1954 the construction of the Trans-Mongolian railway with the length of more than $1100 \mathrm{~km}$, which connected the USSR and the People's Republic of China, was completed. The construction of the railway, carried out in accordance with the Agreement between the Government of the Mongolian People's Republic and the USSR on the establishment of the Soviet-Mongolian joint-stock company "Ulaanbaatar Railway" in 1949, is of great importance for the social and economic development of Mongolia.

In 1956, the Cultural Revolution started. A campaign to improve the health of the population was organized. It was necessary to introduce civilized life and modern culture to Mongolia. As a result of three cultural attacks, the centers of the spread of sexually transmitted diseases were destroyed, and illiteracy was eliminated. Mongolia joined the achievements of scientific and technological progress. By 1959 the collectivization of herdsmen had been completed as a whole. The development of agriculture and the development of virgin lands began. The work on "voluntary" collectivization, on the basis of the Soviet example, started. In 1959, the development of virgin land marked the development of a new branch of agriculture, which resulted in one of the largest revolutions in the history of Mongolia (Niamsuren, 2014).

In 1960 the population of Ulaanbaatar reached 100,000 people. People moved to Ulaanbaatar in large numbers. The urbanization of Mongolia, which led to changes in the social sphere and industry, had begun. With the help of the Soviet state and the countries of the Council for Mutual Economic Assistance (CMEA), the 
institutes, infrastructure and the basis of the country's industry were created.

In 1961 Mongolia became a member of the UN. Since 1946, Mongolia tried to become a member of the UN, but the West and China impeded this for a long time. After Mongolia became a member of the UN and other international organizations, it was recognized throughout the world.

In the early $1960 \mathrm{~s}$ of the $20^{\text {th }}$ century, relationships between the USSR and China deteriorated and led to the armed clashes at the border. In 1967, the Soviet Union brought troops to Mongolia, the total number of Soviet military man reached 75-80 thousand. China concentrated troops on its northern borders.

Under the conditions of the cold war, Mongolia was able to take loans from the USSR. In the period from 1972 to 1990 the Soviet Union granted Mongolia 10 billion rubles, which gave impetus to social and economic development. In 1972, the construction of a mining and processing enterprise for the production of copper and molybdenum concentrate, which started its work in 1980, began in the city of Erdenet. This largest enterprise laid the foundation for the major changes in the Mongolian economy, was among the top ten world leaders, and became the main factor in changing the structure of Mongolia's economy. By 2010, the Russian-Mongolian joint mining and processing enterprise Erdenet, whose injections into the state budget of Mongolia amounted to a half of it, started exporting copper with the label "Made in Mongolia".

From 22 to 30 March 1981, Jügderdemidiin Gurragchaa - the first astronaut of Mongolia made space flight as an astronaut-explorer on spacecraft Soyuz-39 (commander of the crew V.A. Dzhanibekov) and the orbital scientific and research complex Salyut-6 - spacecraft Soyuz $\mathrm{T}-4$. The crew worked in the main expedition consisting of Commander V.V. Kovalenok and flight engineer V.P. Savinykh. The duration of stay in space was 7 days 20 hours 42 minutes and 3 seconds.

\section{Mongolia (the late 20th century till the present time)}

The transformations of the late 1980s of the last century in the Soviet Union and the CMEA countries also had an impact on the Mongolian People's Republic. Thus, on December 10, 1989, the creation of the Democratic Union was declared in Mongolia. Soon democratic and Social Democratic parties of Mongolia were created, which demanded changes in the social structure of the country. In summer, the first free elections were held in Mongolia. The first parliament, the Small Khural, started working on an ongoing basis. P. Ochirbat was elected as the first President of Mongolia. Thus, Mongolia became a free and independent state and moved to an open society and market economy.

In May 1991, the People's Great Khural passed a decision on privatization. By 1993 livestock was completely privatized. At that time, the livestock number was 22 million, and now it is more than 45 million (as of the end of 2013). As of today, $80 \%$ of state property has been privatized. Mongolia approved the democratic Constitution on January 13, 1992 and announced the formation of a republic with parliamentary government. According to the results of the election to the State Great Khural held in 2014, none of the political parties could occupy the majority of seats in the parliament, and a coalition government was formed (Niamsuren, 2014).

As can be seen from the transformation processes of the Mongolian state, 70 years (1921-1991) of its development evidence of close cooperation with the USSR. These years, in the authors' opinion, are one of the important stages in the Mongolian state development, since at that time Mongolia again gained independence, 
defeated the Japanese invaders, and institutes, infrastructure and industry were created.

The modern economy of Mongolia is concentrated in such industries as mining and agriculture. According to the Federal Migration Service of Mongolia in 2013 the population reached 2.9 million people. The majority of Mongolians live in cities. As noted above, at the early and late $20^{\text {th }}$ century Mongolia received large financial and economic assistance from the USSR, its peak took place in 1990. In the following decades, Mongolia experienced a decline in GDP. Thus, as of 2013, GDP per capita is 6053.8 tugriks (Fig. 1). The investment fell by $33.1 \%$. Since the early 2000 , the country started to actively join the global system of attracting investments. Below are the main economic indicators of Mongolia.

Unemployment rate: $9 \%$ (2011).

Export: (4.385 billion dollars in 2011) copper and other non-ferrous metals, fluorspar, uranium ore, coal, oil, clothing, farm animals, wool, skins, animal products, cashmere.

The main buyers in 2011 were China (85.7\%), Canada (6.3\%), and Russia at the $10^{\text {th }}$ place (3\%).
Imports: (6,739 billion dollars in 2012) vehicles and machinery, fuel, cars, food, industrial consumer goods, chemicals, construction materials, cigarettes and tobacco products, household appliances, soaps and detergents, sugar, tea.

The main suppliers in 2011 were China (43.4\%), Russia (23.3\%, mainly oil and electricity), South Korea (5.6 \%) and Japan (5.1\%).

The main trading partners of the country are China and Russia, and Mongolia's economy largely depends on these countries. $68.4 \%$ of Mongolia's goods were exported to China, while imports accounted for only $29.8 \%$. Mongolia imports about $95 \%$ of oil products and part of electricity from Russia.

\section{Conclusion}

Since the 1990s, in connection with the changes in the social and economic system of public administration of Mongolia, compulsory privatization started and, as a result, state enterprises started to be transformed into open joint-stock companies. The shares were distributed to the entire population in the form of

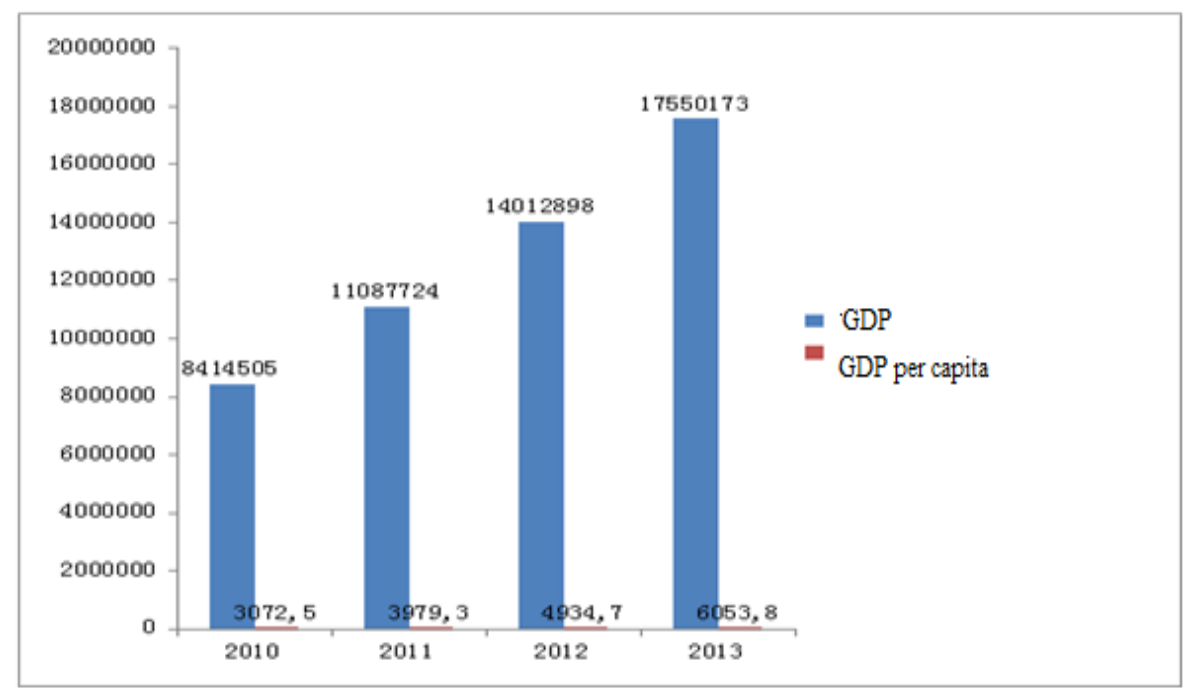

Fig. 1. GDP and GDP per capita of Mongolian population, in tugriks 
ribbons of different colors despite the fact that the people were not enough economically educated, and most of the population did not attach significance to this, at best investing into the organizations they were working for (Niamsuren, 2014). As a consequence of such processes, a proprietary model of corporate governance (as in other countries) was subsequently established. It has some features of different management models and a number of downsides: a low level of information about the companies' activities; absence of transparent and fair rules of the game, similar for all the subjects of economic activity; inefficiency of the mechanisms for the redistribution of property in favor of efficient owners; to counter uncertainties in the external environment and its pressure, managers view the option that significant proportion of affiliated persons in the ownership structure of controlling stakes should be concentrated in the same hands as a necessary condition; absence of a smart dividend policy, which led to the fact that the level of dividends paid was very low; high staff turnover; introduction of Western management models without taking into account national peculiarities actions to adapt to the corporate governance system.

Competitive Mongolian companies are now being transformed into large corporations that are quite successfully developing in different spheres of activity, thereby expanding their boundaries. Along with this, the number of employees that should be motivated to achieve the corporation goals is gradually growing.
However, the formation and development of the contemporary management model for the Mongolian joint-stock companies, whose activities go beyond geographic boundaries, cannot occur without taking into account: a) the features of the historical development of national culture, since it has been forming a mental model of the bearers of this culture for a long period of historical development of the people; b) the impact on Mongolian corporations and their viability, exerted by an external factor - the factor of the world globalization.

All these aspects of culture interact and mutually influence each other, thus forming a mixture of cultures - a specific culture of a mixed type, characteristic of modern Mongolian corporate governance. Under the influence of this factor over the companies and corporations operating in world markets and wishing to ensure competitiveness is updated due to the constantly changing demands of the external world. Consequently, the national model of management for Mongolian corporations should be based on and take into account: a) specific features and values of the national culture of the country; $b$ ) the factors of the national organizational culture, which is formed under the influence of the national historical culture of Mongolia; c) the factors of globalization and internationalization that require continuous strategic renewal of corporations through cultural dynamics, transdisciplinary and transfunctional approaches to the formation of a national mental model of Mongolian corporate management.

Classification of Corporate Governance Models. See, for example: Bor, A., Sevek, V.K., Dongak, C.G. (2016). Theoretical Foundations of the Model of Corporate Governance in the Context of Globalization, In European Social Science Journal, 5. Noyan is a secular feudal, prince in Mongolia.

\section{References}

Bor, A., Sevek, V.K., Dongak. C.G. (2016). Theoretical Foundations of the Model of Corporate Governance in the Context of Globalization, In Evropeiskii zhurnal sotsial'nykh nauk [European Social Science Journal], 5. 
Dash-Yondon, B. (2013). The Philosophy of Mongolia's Development. Ulaanbaatar, Selengepress HHK.

Gerelmaa, G., Odmandakh, M. (2007). Traditions of Mongolia, In Sb. nauch. Tr. Hureltogoot-2007 [Collection of Research Papers], Ulaanbaatar, Akademia.

Kovalenko, B.B., Semenchenko, T. (2014). Corporate Culture-a Factor of Success in Entrepreneurial Activity, In Nauchnyi Zhurnal NIU INMO, seria "Ekonomika i ekologicheskii mededzhment” [Scientific Journal of NIITMO, Series "Economics and Environmental Management”], 3.

Kovalenko, B.B., Semenchenko, T.V. (2015). Phenomenon of Corporate Culture: Diagnostics of the State and Methods of Change, In Nauchnyi Zhurnal NIU INMO, seria "konomika i ekolo cheskii mededzhment" [Scientific Journal of NIITMO, Series “Economics and Environmental Management"], $1(20)$.

Lhaasid, D., Badralmaa, R. (1996). Strategic Management. Ulaanbaatar, Publishing House of the UPR.

Narantsetseg, P. (2007). Specificity of Mongolian Management. Ulaanbaatar, BCI.

Niamsuren, Zh. (2014). 90 Years of Development. Ulaanbaatar, Munhiinuseg.

Savchenko, L.S. (2008). Organizational Culture and Competitiveness of Entrepreneurship, In Rossiiskoe predprinematel'stvo [Russian Entrepreneurship], 3, 1 (107), 64-67.

Savchenko, L.S. (2005). Evaluation of the Effectiveness of the Organizational Culture of Entrepreneurship, In Rossiiskoe predprinematel'stvo [Russian Entrepreneurship], 12 (72), 41-47.

Sevek, V.K. (2015). Notes on Mongolia (Part One), In Tuvinskii universitet [Tuva University], 8 (69), 7. [Electronic resource]. Available at: http:/tuvsu.ru/upload/osnovnoy/banner/8\%202015.pdf.

Sevek, V.K. (2016a). Notes on Mongolia (Part Three), In Tuvinskii universitet [Tuva University], $5(74), 15$.

Sevek, V.K. (2016b). Notes on Mongolia (Part Two), In Tuvinskii universitet [Tuva University], 2 (71), 7. [Electronic resource]. Available at: http://tuvsu.ru/upload/osnovnoy/banner/2\%202016.pdf.

Sevek, V.K., Batzhargal, D., Sevek, R.M., Dongak, Ch.G., Manchyk-Sat, Ch.S., Mongush, O.N. (2016). The Market of Educational Services in the Context of Combined Educational Programmes, In Ekonomika: vchera, segodnia, zavtra [Economics: Yesterday, Today, Tomorrow], 3, 237-250.

Sevek, V.K., Dorligzhavyn, B., Sevek, R.M., Dongak, Ch.G., Mongush, O.N. (2016). The Mechanism of Implementation of Network Forms of Educational Programmes Using Distance Educational Technologies, In Nauchnoe obozrenie [Scientific Review], 8, 245-250. 


\title{
Анализ национальных особенностей \\ и проблем развития \\ организационной культуры Монголии
}

\author{
В.К. Севек ${ }^{\mathrm{a}}$, А. Бор ${ }^{\boldsymbol{\sigma}}$, Р.М. Севек \\ а Тувинский государственный университет \\ Россия, 667000, Республика Тыва, Кызыл, \\ ул. Ленина, 36 \\ ${ }^{\sigma}$ Институт финансов и экономики \\ Монголия, 13381, Улан-Батор, пр. Мира, 5
}

В статье представлен анализ национальных особенностей организационной культуры Монголии с учетом исследования ее исторического этапа развития. Цель работы - определить современную национальную модель управления монгольскими корпорациями. Методом исследования являлось определение факторов национальной организачионной культуры на основе анализа этапов развития монгольского государства, начиная с культуры кочевников до урбанизированной современной культуры. Выявлено, что все эти культуры взаимодействуют и взаимовлияют друг на друга и тем самым образуют некую смесь культур - особую культуру смешанного типа, характерную для современного монгольского корпоративного управления. Влияние данного фактора на компании и корпорачии, действующие на мировых рынках и желающие обеспечить конкурентоспособность, обновляется в силу непрерывно изменяющихся требований внешнего мира.

Ключевые слова: анализ, начиональная культура, организационная культура, компания, корпорациия, управление, Монголия.

Научная специальность: 24.00.00 - культурология. 